NPS ARCHIVE 1962

EDGREN, D.

\title{
INVESTIGATION OF THE INFLUENCES \\ ON THE MIXED-LAYER DEPTH \\ DURING THE COOLING SEASON
}

\author{
DONALD H. EDGREN \\ and \\ JOHN J. MACPHERSON
}






INTESTIGATTON OF

THE IITLUFICES ON THA IIXSD-LAYKR DEPTH

DURING THE CCOIING SEASON

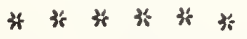

Donald II. Edgren

and

John .T. MacPherson 

IITESTIGATIOIT OF

TIR IIFLUEISCES OIT TIT, ITXED-LAYHR DEPTH

DURING TIE COOIIIIG SEASOII

\author{
by \\ Donald H. Fidzren \\ Lieutenant, United States Navy \\ and \\ John J. MncPherson \\ Lieutenant Cormandor, United States Navy
}

Submitted in jartial fulfillment of the requirements for the degree of

MASTHR OF SCIENGT

IN

IFTEOROLOGY

United States Naval Postgraduate School Monterey, California

1962 
$1910=$

syopey: 
TITESTIGATION OF

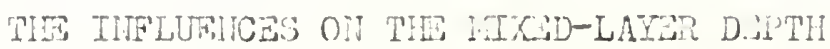

DURTIA PIP COOLIM SEASOH

\author{
by \\ Donsld H. Fderen \\ and \\ John J. MacPherson
}

This work is accopted as fulfilling

the thesis requiroments for the degree of MASTIR OP SCTPNC:

III

RETEOROLOGY

from the

United States Naval Postgraduate School 



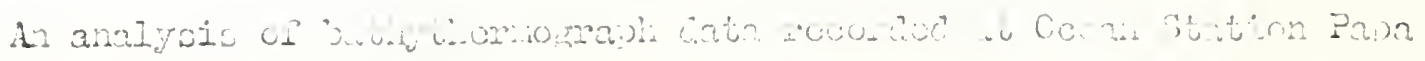

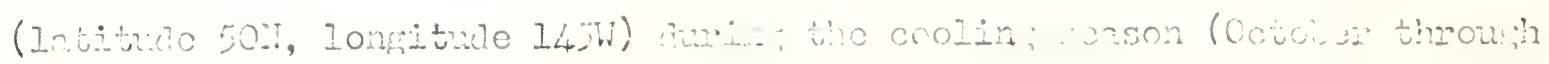
Docomber) indicates that the annual decpening and whboruent docay of the seasonal themocline is accompanied by many randon fluctuntions. The physical processes causing the decay and the fluctuations in the mirodlayer depth are cxarined and qualitatively ovaluated.

The Thkey spectrun malysis promamed for the CDC 1604 electronic dieital computer was used in analysis of nscillations at tho botton of the mixcd layer to detorrano the distribution of wave cnercy for serjes of data taken at hourly intervals. An cnergy pea: centered near 12 hours was obsorved to prodoninate, and this encrgy is equivalent to that of a 12-hour internal wave with height of 27.0 feet. The cormouter was also used to select the sisnificant noteorological and oceanographic parameters which could be usec: to rredict a change in the mized-layer depth by use of the BIID O7 mutiple regression progron. The most signifj.cant parameter was sea surface temperature. The best correlation coefficient for this parancter occurred for lags of zero to 12 hours.

The results of the analysis support the theory that convection is the physical process which causes the seasonal docay of the thermocline during the cooling season an? that short-term fluctuations of the mixed-layer depth are due primarily to internal waves.

The authors wish to express their appreciation for the assistance and oncourasement given ther by Associate Professors G. H. Jung and T. B. Wickham, and by Professor D. A. Williams and the staff of tho computer center at the U. S. liaval Postgraduate School in this investigation. The authors also wish to thank the Pacific Oconnocraphic Groun of Canada for ralking the occanoraphic data available. 

TABIE UF CONTEITS

Section

Title

Page

1. Introduction

1

2. Background 3

3. Description of Ocean Station Papa 4

4. Review of Temperature and Salinity Structure 5 during the Cooling Season

5.a. Objoct

b. Method of Investigation 6

6. Analysis of Internal Waves 11

7. Conclusions and Recomendations 16

8. Bibliography 36

Appendix

Heat Transport in the Sea and Fxchange across the Air-Sea Interface 

Figure

1. Iocation of Ocean Station Papa

2. Position-Indicating Crid for Ocean Weather Station Papa, with a Viercator Projection of a Latitude and Ioncitude Grid Superimposed

3. Decay of the Thermocline (1956) 20

4. Salinity Structure in Eastern Subarctic Pacific Occan

5.a. Cross-Spectrum - IID and Sea-Surface Tenperature Time Series (Novenber, 1958)

b. Cross-Spectrum - IID and Sec-Surface Tomperature Time Series (October. 1956)

6. Mean IID and Sen-Surface Temperature (October through December. 1957 and 1958)

7. Average Daily MID (October through December. 1956)

8. Hourly Time Series of Min (November, 1958)

9. Hourly Time Series of MTD (December, 1956)

10. Hourly Tine Series of Thermocline Thickness (November, 1958)

11. Correlogran for One-Hourly Time Series (October, 1957 and November. 1958)

12. Encrsj-Density Spectrum (November, 1958) 28

13. Encrgy-Density Spectrum (October, 1957) 

Table

Page

I Bathythertograph Soundings Available

II Simple Linear Correlation Coefficients between the 18 Primary Parameters and the I.ID

II Sirale Linear Correla'ion Coefficients for Sea-Surfice T'emperatures and the IID

IV Regression Results for One Independent Variable

$V \quad$ Maltiple-Regression Results for 18 Independent Variables

VI Three-Year Averages of Regression Results 



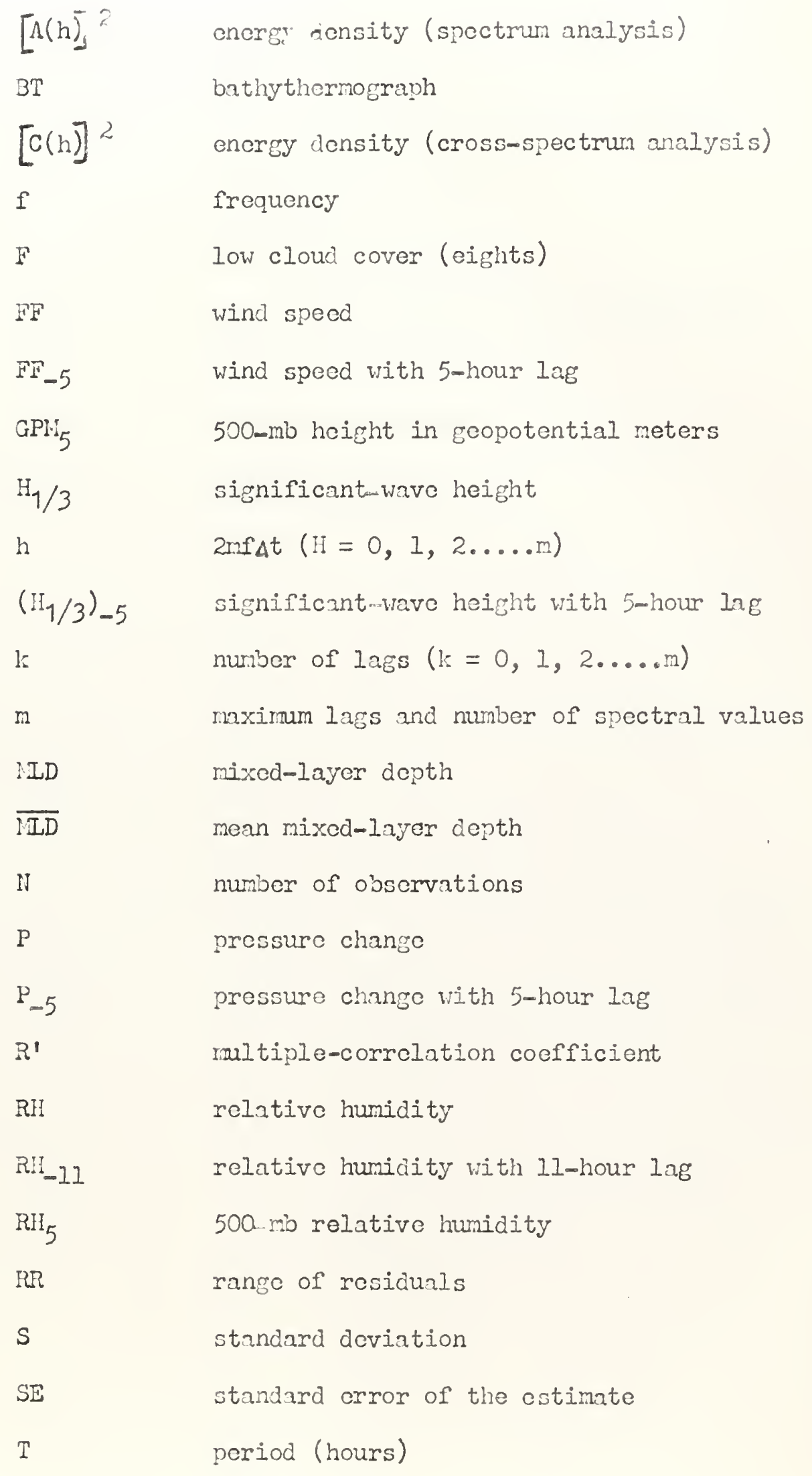

significantwwave height

$2 n f \Delta t(H=0,1,2 \ldots . m)$

significant..wave height with 5-hour lag nurber of $\operatorname{lags}(k=0,1,2 \ldots . . m)$

maximum lags and number of spectral values mixed-layer depth

mean mixed-layer depth

number of obscrvations

pressure change

pressure change with 5-hour lag

raltiple-corrclation coefficient

relative humidity

relative humidity with 11-hour lag

500 mb relative humidity

range of residuals

standard deviation

standard orror of the estimate

period (hours) 
. 


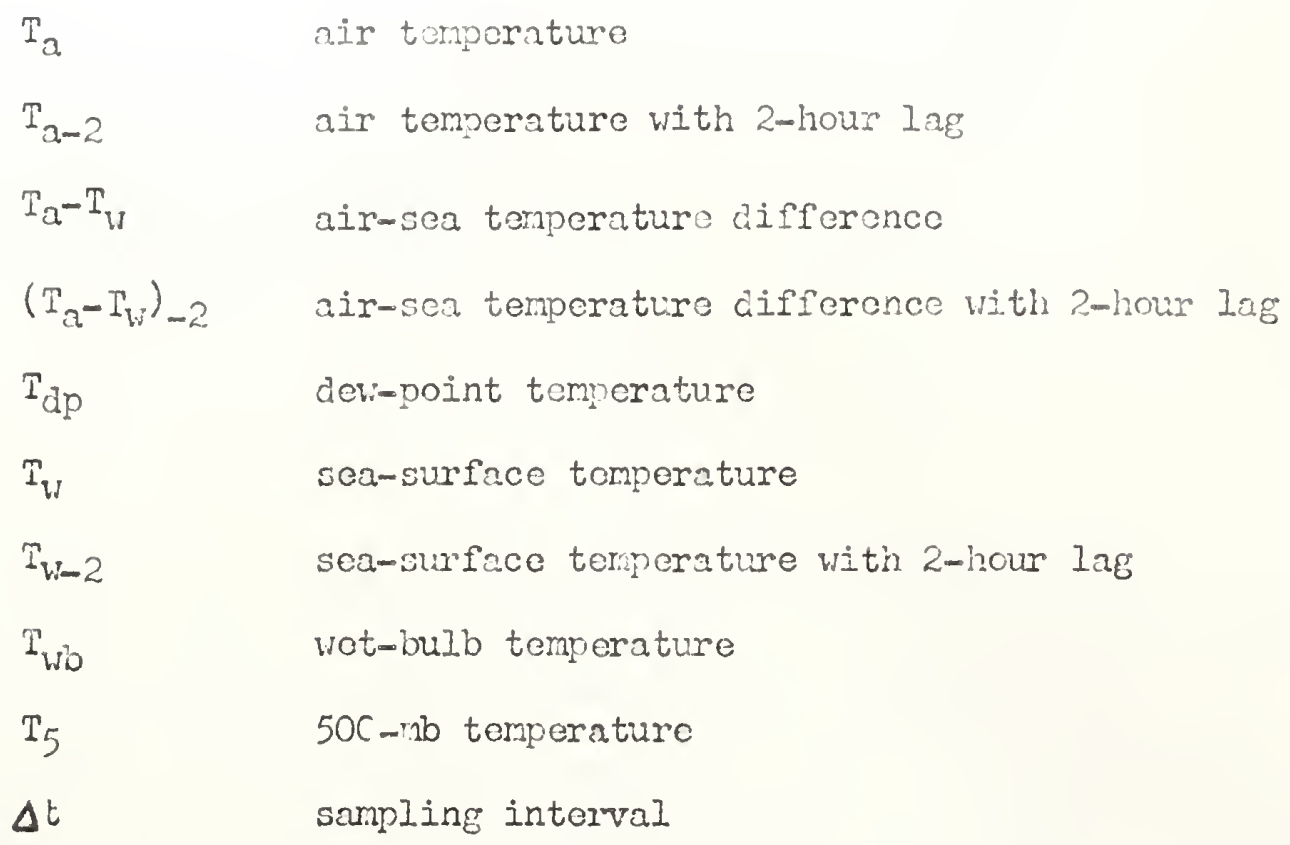



The vortical comprature structure of the near-surface layer in the open occan is a complicated phenomenon which varies in space and time. Cortain aspects of the teinperature structure are of great significance in determining sonar effectiveness. Thus, both the military and the commercial fishing industries are interested in prediction of the thermal structurc.

Various processes continually modify the thermal stmucture to produce an essentially homoseneous (mixed) surface layer, underlain by a thin layer of rapidly increasing donsity, which varies in thickness throughout the yoar. The nixedmlayer depth (referred to as the IID) is the depth bolow the water surface to which mixing has established isothermal conditions. The lower boundary of the ILD is the top of the thermocline, a thin layer of large, negative vertical temperature gradient, usually associated with the layer of increasing density. A complex interaction of meteorological, occanographic, and (indirectly) astronomical factors provide the driving forces for changes in the ocean thermal structure.

Random and periodic fluctuations of the VLD have been cxamined by many investigators. It is known, as a result, that the IID may vary from a fow inches in the heating season to several hundred foet in the cooling soason. At tines it may fluctuato tens of feet in a matter of minutes.

The objective of this resenrch is to identify more clearly significant processes which affect the IID during the cooling season and to relate the IID to meteorological and occanographic parameters. The processes capable of affecting the vertical tomperature distribution are discussed in the appendix. Certain of these processes will be considered in this paper: (1) thermohaline convection, (2) dynamic convection duc to wind and wave action, and (3) unidentified processes which gencrate internal waves. 



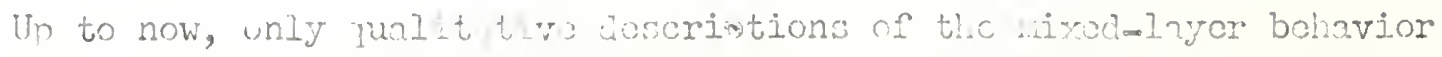
during tho cooline season aro found in the litorature. Tisso usually state that increased wind stirring and surface cooling act torsther during the cooling season to drive the scasonal thormocline down to its maximu annual depth. Our findings will show that, at Station Papa, thomohaline convection is the most important factor and that vind mixing (dynamic convection) is actually insignificant during the cooling scason.

Heteorological and occanographic parancters contributing significantly to tho chanģ in the VD during the cooling scason aro determincel, and from these the physical processes of importance are inferred. The investigation was carried out with the aid of statistical corrolation and wava analysis prograns, the BIID O7 [16] and the Tukcy spectrun analysis [15], utilizing the CDC 1604 digital computor. Regression cquations and corrolation coefficients are obtained by the BIID 07 program. One part of the Tukey spectmum analysis was used to determine cross spectra of the IID fluctuations and the sca-surface tomperatures. This program was also uscd in the analysis of internal waves.

The investigation is based on occanographic and weathor data obtaincd by the Fisherics Rcscarch Board of Canada, Pacific Occanographic Croup, for the months of nctober, Novomber, and Decomber during the yoars 1956, 1957 and $1958[6,7]$. 

2. Backniound

The attempt to identify the factors which bring about the hourly fluctuations in the IID was based on the authors' anrlicr endeavor to dcrive an cmirical method to prodict the average M.D on a daily basis during the cooling scason. It becano apparent then that the hourly fluctuations of the IID could be of equal or largor magnitude than the average decroning of the lith ciuring one or more days; thus, to usc one or an average of two or more observed iLD values per day as representative of the dopth for any particular hour of that day is misleading [!]. The probable causc of these fluctuations is intornal vovos.

Students at the U. S. Waval Postgraduate School during 1961 and 1962 derived ompirical nethods to predict the ITD at Ocoan Station Papa during each of the 12 months of the yerr. In addition, the onset of the seasonal thomocline at Ocean Station Papa, which takes place in Apriz or liay, was studied by clark in 1961. [2]. Clark successfully rolated the therrocline onset to upper-air paramoters. During the heating senson, when the soasonal thermocline sradually increases in magnitude, wind mixing procosscs have becn clcarly establishod as the dominant factor in determining tho i.ID, by Tabate [2] and Cenry [10] in 1961. The cooling season remains to be stridicd. Wo have made this attompt. 

3. Doscription of Ocoun Station Papa

The Eoographic location of Occan Station Papa is 50N, 145W (figurc 1). It is approximately 400 milos north of the boundary betwecn the castern subarctic water mass and the subtropic vater mass [8]. The water depth at Papa's locotion is 2000 fathoms therefore, the thermal structure is in no way influenced by bottorn topography. Also, its location is approximatcly in the conter of the Alaskan Current Cryal [o:9] (figuro 1). Because of this location, the effects of advection are minimized and vill not be considered.

The wonther ship nomally mantains an on-station position vithin a termile square contered on 501, 145W. In ordor to avoid rough weather, the ship my stcom anywhe vithin the 210-mile square grid (ficure 2 ). Each bathythermograph (BI) sounling is identified by a two-lettor codo. If the ship is on-station, the lotter group OS indicates the position. The ship position for the sroater part of the period of our concorn was Within a 30-mile square contored at OS. Any data outside of this 30-milc square were not considered in this study. 



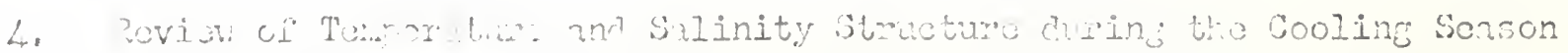

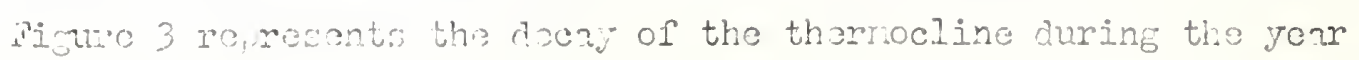

1256. In Auzust, tic curface lnjers have bocn heated to a masimum, approximately 57F. Due primarily to wind rizing, thore is a shallow mixad layror approximtoly 100 foot in denth with a sharp underlyine thomocline. Within the themocline, the vater tomporature drons to $40 \mathrm{OF}$ at 3 depth of 200 feet. Progressing into the fall and winter, tho MiD continually increases and the magnitude of the themocline decroases. By tho ond of Decomber, the IID is nocrly 330 feet in dopth; and the ses-surface tomporsture has iccreased to approximately $42 \mathrm{~F}$. Due to the presence of an intense halocline, the W.D renchss a limiting depth of 330 fect in January, and isothomal conditions provail down to this dopth for the remainder of the wintor.

The basic salinity structure for the eastern subarctic Pacific watcr mass is shown in figure 4. Throe zoncs arc inaicated. The uppor zone cxtends from the sca surface to a depth of 330 fect, and is charactcrized by rolatively low-salinity wator (32.7\%) [21]. In the rall, the upper zone is isohaline and is marred by the prosence of the soasuml therroclinc. Because of the isolaline conditions in the upner 330 feet, wo 3.ssume that significant variation in density is govornod by changos in tomperature only.

Tho halocine represents a transition zono botwoon the uppor and Iover zonos. Fore, the salinity incrosses malsody with dopth (as much as one part per thousand vithin an interval of 330 feet). The halocline roprosonts a liniting donth for the sonsonal thumocline. Tt is sinilar to having an ocean botton at this dopth as far as convective mixing is concornod. The donsity increaso is so great through this layer that mixing cannot take place through it [20]. Within the lower zone ( $>$ (150 fent)

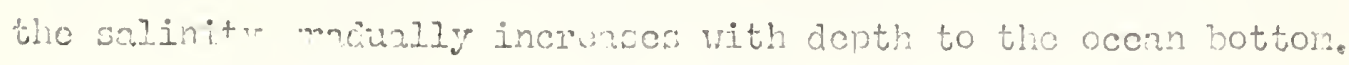



$5 . \operatorname{coject}$

Tho Mirpose of this statistical study of the ITD is threc-pold. An attompt is made: (1) to detemine the relative importanco of thermohaline convective mixing and wind-induced mixing on the decpening of the thermoclinc during the cooling season; (2) to determine the lag between a significant metcorological or oceanographic event and a subsequent change in the IIL; and (3) to examine the importance of the sceningly random short-term fluctuations of the $M I D$ and to provide a description of those intornal wavos prosent.

First, the parameter or parameters are identificd which have the largest lincar correlation with the deepening of the $\mathrm{KI}, \mathrm{D}$. Next, a further investigation has been undertaken of these significant parameters to detormine the lag in the mixing proeess, that is, the time between the onset of a change in the parameter and a subscquent deepening of the IIDD. Finally, the observed variations in the IID which cannot be accounted for by either mixing process are investigated.

\section{5.b. Method of Investigation}

The parameters to be investigated are sub-divided into threc groups. Those related to convective stirring are: (1) temperature of the sca, at the tine of the sounding and with a 2-hour lag; (2) air temperature, at the time of the sounding and with a 2-hour lag; (3) dev-point temperature and wet-bulb temperature, at the time of the sounding; (4) relative hunidity, at 2-hour and 5-hour lags; and (5) low-cloud cover, with a 2hour IaE.

Parameters chosen to represent wind and wave mixing are: (1) wind speed, at 2-hour and 5-hour lags; and (2) height of significant waves, at 2-hour and 5-hour lags. 

Parameters chosen which vero shown to have a corrolation with the thorral structure by othors in previous studics, but did not convonicntly fall into the abore catogorics, are: (1) 500 mb reight, in geopotential neters; (2) 500-mb temperature and 500-mb relative hunidity, at a 2-hour lag; and (3) surface-pressure change, with a 2-hour and 5-hour lag.

These data were obtained from synoptic 3-hourly reports, twice-daily constant-pressure records, and the BT traces. The available BT's for the period of investigation wero tabulated in two groups, $0200 z$ and $1700 z$, for cach your to eliminate any possible yoarly anomalics or diurnal trends. An investigation by Scripps Institution of Occanography of the annual ILD fluctuation in the northoastern Pacific Occan shows that the MLD nost froquently nhsorved in a given month often varies considerably from yocr to year [] $]$. The available litersture on diurnal tronds during the cooling season is not so clear. A preliminary investigation of the data showed no marked diurnal trend. This indication was supported by Dr. Tully of the Pacific Oceanographic Group, in a convorsation with the authors, in which he stated thai during the cooling scason the MLD is too decp to have a clearly defined diurnal filuctuation.

With the aid of a multipla-rogression and corrolation analysis, the BIID 07 programmed for the CDC 1604 high-speed cormuter, the linearcorrclation coefficients were obtained for the pre-selected group of meteorological and oceanographic parameters with the iLD. The BID or program vas used because it can sclect different sub-samplos of data that are obtained from the sane population. Thus, the program would porfom Iincar-correlation analysis and lincar mutiple regression on the data for 02007 and 1700z, scparatcly and in corbination. In this way, a close cxamination of possible diurnal trends could be made for each of the three years studicd, 1956 through 1958. The analysis provided rogression equations 

for nine difforent data groups for the poriods show in 'lable I.

The BIID 07 program yields best results when the number of independent variables is not grester than onc-half the number of values of the dependent variable. Since the smallest number of values for the dopendent variable is 36 (at 0200z, 1958) ${ }^{1}$, only 18 indepencient variables werc investigated. A set of 18 socondary parameters vas tabulated in the event that the analysis of the 18 primary parameters proved inconclusive.

There vas no attompt by tho authors to eliminate possible duplication of parameters that are indicative of the same process. For example, dowpoint temporature, wet-bulb temperature, relative humidity, and low-cloud cover are all related to cvaporation; but it was loft to the BIIn o7 program to discern which ones, if any, were significant in contributing to the prodiction of the deepening of the IID.

The BIMD 07 is unable to produce a multiple linear-regression equation if any independent variable is a lincar combination of two or more independent variables. Therefore, temperature of the air minus temperature of the sea, which is often used as an indicator of thermohaline convection, colld not be investigated in conjunction with the air temperature and sea tomprature. Consequently, threc additional problems wore computed using the air-minus-sce tompcrature parameter in place of sea-temperature parameters. Sco Table II for the tabulited results of the 12 problems.

Tn analysis of all tho data, certain facts and tondoneios aro evident; these are discussed in the rollowing two paragraphs.

The only paranoters that show a consistently high linear correlation With the III in every sample or sub-sample are the sca-surface terporaturos, at the time of $e$ sounding and with a 2-hour lag. Thoy also accounted

1(This small number rosults bocauso BT data for October, $195 \%$ arc rissing; only a small number of observations was available in 1957 as well, since Decomber, 1957, obscrvations were not taken.) 

for almost all of the variance explaincd by the regrossion cquation using 211.18 paraneters. Figure 4 shows the close relationship between the scamsurface tomporature and the IID from October through Decomber, 1958. Likerisc, Zcttcl [25] suggested that sca-surface temperature might be a. good "indicator" for the ILD.

Wind specd and height of the significant waves, the parameters chosen as indicators of wind stirring, have either very low nogative or Iow positive correlation coefficients.

In order to determine the time required for an increase in convsetive activity due to a reduction of sea-surface tompcrature to effect a sub sequent decpening of the NID, the ILD's for 1700z, 1956, wore tabulated with the sea temporaturo at lags of zoro, two, five, eight, cleven, fourteen, scventeon, twenty-one, and twenty-threc hours as the independent variables. A simple linear-correlation progran was uscd to deternine that the lag yiclding the best correlation was two hours (Table III). Also, two one-hourly serics of MID for 79 hours in October, 1957, and for 51 hours in Novomber, 1958, were tabulatod with thoir corresponding sea-surface tomperatures. The energyodensity spectmu and the cross-spectrum of both the IID and the sea-surface-temperature time series was obtained fron the Tukcy analysis. Maximum lags of 39 hours and 24 hours were used for the 79-hour and 51-hour scries respectively. The twe cospectic for the 79-hour and the 51-hour scries show large values for h's around 8 hours and 4 hours respectively (figure 5).

From the results of the simple lincar correlation and the Tukey analysis, I it is scen that all lags from two to sto hours show high corrclation. Beyond 12 hours the correlation rapidly decrosses.

A Iinsar-regression equation was derived for 17007, 1956, using sea tomperature with a 2-hour lag as the single independent variable (Table IV). 

The fact that the results of this equation as measurod by the standard orror compare favorably with the multipla-regression equation derived from 18 independent variables for the sane year supports the initial analysis of the problen. If a regression equation were to be used to forecast IID, one using only the sca-surface temperature taken with a lag of up to 12 hours would be much moro reliable than an equation with more parameters. This is true simply because it would have a larger number of degrees of frecdom. Note that all of the regrossion equations have a standard orror of from 15 to 30 fect, with an average for all problems of 22.15 fect (Table V. Table VI).

There are several possible explanations for this standard error of more than 20 feet: (1) it is possible that not enough parameters were used, and that by substituting for primary parameters which showed a very poor correlation, some of tho secondary parameters or primary parameters with different lags, the stanlard error of the new regression equation would be reduced; or (2) there is a strong possibility that a non-linear relationship between a parameter and the IID could account for a large part of the standard error (however, the BIMD 07 program cannot detect this); or (3) the orror may be due to internal waves. Of these possibilities, (3) scems the most likely reason to explain tho observed standard crror. 

6. Analysis of Inturnal Waves

The base of the nixed layor in the occan is subject to many vertical oscillations. Figure 7 shows a serios of daily liL's for tho periou October through Decenbor, 1256. Wach plotted point on the curve is an averago daily value of the IJD. Two individual soundings are normally used; however, up to 24 soundings were available on several days. It is obsorved that the MID undergoes a seasonal downward trend. During the October through Decenber poriod, the scasonal trend of the MID finds it increasing from approximately 130 fect to 330 feet. This is an average decpening of 2.17 feet per day. Also, large vertical fluctuations are superimposed on this downward trend, which become largar in magnitude as the mixed-layor thickness increases. Note in figure 7 that the vertical fluctuations of the KD can be ten tines greater than the average daily deepening. In addition, it is scen (figure 8 ) that hourly fluctuations can be of equal or greater magnitude than the average daily deepening during the fall.

Fisure 8 represents a one-hourly time series for 51 consecutive hours during November, 1258 (scries 1). A second onc-hourly tine series reprosents 79 consecutive observations taken during October, 1957 (series 2). The magnitude of the IID fluctuations is about the same, whether it $i:$ computed from hourly, twice-daily, or daily observations. The average fluctuation por hour of the IJD for series 1 is 18 feet. The average fluctuation betweon the consccutive $0200 z$ and $1700 z$ soundings for the month of Noveraber, 1958, is 21 feet. Also, the averaged daily fluctuations during llovember is 25 feet. The numbers for series 2 are similar. A Decomber, 1956, one-hourly time series (figure 9) was available but was too short for detailed analysis. However, it illustrates the extrone fluctuation of the ILD which takes place over a short time interval. Over a 3-hour 



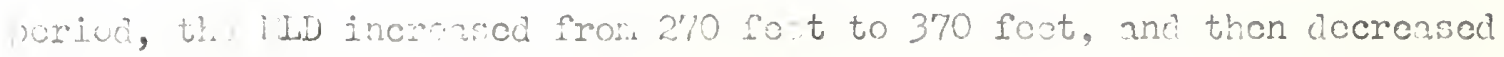
again to 235 foct.

Since mixing processcs can account for only an increase in the lid, and since obscrved fluctuations are in both directions (up and dovn), and are a consistent feature of the date, these observed fluctuations are considercd to be duc to internal waves.

Internal waves may occur within stratificd water and in water in which the density increases with depth. The largest vertical displacements of the water particles are to be found within the boundary between layers of different density. The displacoment amplitude diminishes above and below this boundary, approaching zero at the sea surface and the ocean bottom. The density difference between the waters above and below the scasonal thermocline is, of course, much less than the density difference between the air and the water at the sea surface. Therefore, a bounciary within the ocean can be meh more casily displaced than the surface of the sea [17] Ufford [24] states that surface waves require 30,000 times more cnergy to start and maintain than is required for internal waves of the same amplitude. Encrey for internal waves could cone from surface disturbances or from currents within the ocean.

Besides rapid vertical oscillations in the $I I D$, it was obscrved that the thickness (or vertical cxtent) of the thormocline layer below the 1.ID may vary markedly with time. Figure 10 shows the thermocline thickness for sories 1. Variations in the thomocline thicknoss indicate that internal-wave charactoristics of phase and amplitude vary with depth. Also, the temperaturo gradient in the thermocline varies markody becuuse of changes in its thicknoss. Tho actual tomorature difforonc through the therrocline is a rolntivel" stable fecture and is tharofore predictable $[17]$. 



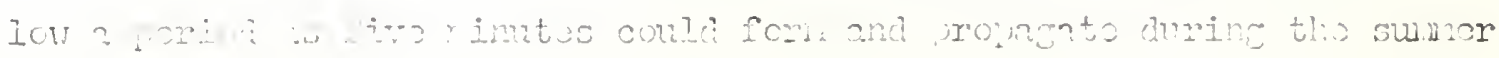
at the level of the smasonal thariocline at Ocsan Station rop. With onc-hourly obeurations milable for answyis, tho minimum noriod tiat could bo insortigntod is tio hours.

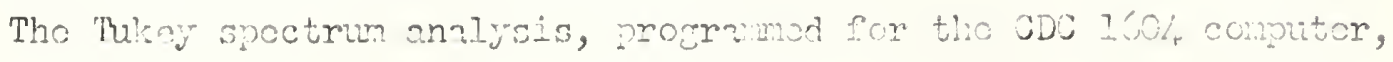
was uses? to annlyzo cach timo sorios. The min objoct was to fine any

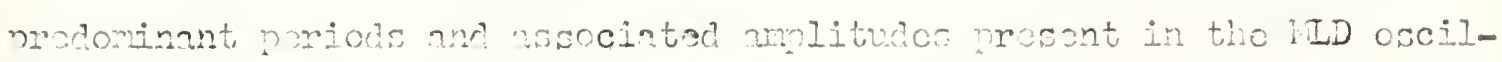

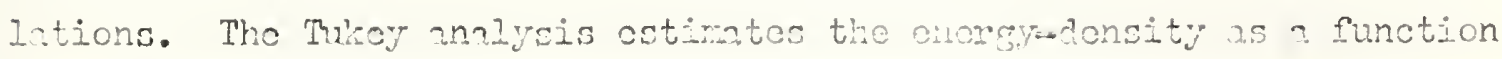
of poxind in a juon corios. This is done by competing tho rutomeorrelation function for a mubu of riven Iags in tho sorios; then a smoothad spoctral ostirnte is ubtaind from the Fomior cosine transform of the suto-corrolation finction.

Initinlyy, a corrolorra vas plotted for both time sories (ficure II). The corrologran is a plot of the non-nomalized auto-correlation cocfincients as a function of the Ine $(\mathrm{k})$. Inspection of this corrolocrar appears to inilcate that the spectmon of series 1 has a relatively large onorgjdonsity raximu noar the l2-hour orjod and a socondary maximur with a peak noar sixhours; and that the spectmum of scries 2 has only one naximum near 12 hours.

Next, the cnorgy-density spectrum of both time sorics vas obtained from the Tuley analysis. Figure 12 is a plot of the cnergy-density spectmu for series 1. A maximum lag (m) of 24 hours was used, which alloved the spectrim to include a range of poriods from two hours through 48 hours. The spectmim helps confirm the indications of the corrologram. A maximum of cnorgy of the variance of the iTid is shown to be produced by fluctuations with periods on the order of 12 hours. Also, a large energy-density is indicated for periods around six hours. Thore is an encrgy gap for the 

periods around cight hours, and the oncrgy for griode less thon five hours crons off rapidly to on insignificant anount.

The total encrgy is a known quantity, oqual to twice tho variance. By mosuring total area under the spectrum curve and the area under each frequency poak between half-cnergy points, equivalent amplitudes for waves vith poriods noar 12 hours and six hours vere computed. These computed amplitudes are 18 feet and 12 fect for the 12-hour and the 6-hour periods, rospectively.

The encrgy-density spectrum for scries 2 is shown in figure 13. A maximun lag $(\mathrm{m})$ of 30 hours was used, which allowed inspection of poriods ranging from two hours through 60 hours. A relatively large cnergy maximu is again indicated for periods arcund 12 hour's. The curre then falls off. rapidly, but shows a slight maximum near the 6-hour range of poriods. A single sine vave with energy cquivalent to that under tho 12 -hour peak would have an amplitude of nine fect.

This analysis reveals three features of the thermal stmeture at Ocean Station Papa during the time interval investigated.

(I) Iartical oscillations of the MD are present at the thermocline curing the cooling scason. The magnitudes of these oscillations are similar in all data, whother they be from hourly, twice-daily, or daily observations.

(2) Although the time series available was much too short on which to basc strong conclusions, the analysis did roveal that the mjor encrgy poaks occurred with a period of approxirately 12 hours with an average amplitude of 13.5 fect.

(3) The value of the standard error of cstimate resulting from the BIID Or regression equations is very close to the height of the postulated 12-hour wave (that is, 27 foet). Thereforc, it is concluded that there 

Is a diroct relation between this orror and tho prescnco of intornal mues durine the poriod of investigation. 
7. Conclusions and Recoruchdations

As a result of this study of the influences on the lid during the cooling scason, the following conclusions can be reachea.

(1) Thermohaline convection is tho important process for the decpening of the I.I.D in the auturin season.

(2) During the period of study, the MD is too decp to be affectod by wave stirring or diurnal trends.

(3) Tha tine lag between surface cooling and decpening of the IID by the convective process is small; this suggests that once the cooling scason begins, convective circulation is cssentially continuous. This circulation may be mintrined during periods of near-zoro hoat frux across the air-sea interface by wind enorgy, as suggestod by JaFond [13]; however, until an injection of potential oncrgy in the form of rapid surface cooling, the MD will renain relatively static. If the increased surface density causod by surface cooling is sufficiont, the convective circulation intensifies and drives the WLD deoper.

(4) A major portion of the MD variability appears to be associated with internal veves. The analysis of internal waves revealed that the major encrey pealis occurred with a period of approximately 12 hours with an average amplitude of 1.3 .5 fect.

Farly in 1953, at a Nivy-sponsored thermocline conference attended by 20 of this country's most prominent occanosmaphers and metcorologists, the following question was asked his colleagues by Dr. T. F. Vialono: "How accurate a prediction of the IID and its hourly fluctuations is requircd by the military?" [19] This remins a vital question.

If the military is willing to necept forecosts of the IDD within ranges of 20 or 30 fect, then existing methods of prediction will suffice. Any increase in accuracy over cxisting schemes for predicting the $1 L D$ at 

a preticulm hour on a maticular day can bo accomplishod in aroas whoro internal waves are important only after prediction of the internal wave pattern is nossible. This is a complicated problem.

If a sufficiently lon, detailed tine series of BT's could be made available, internal waves could be filtered out by use of a technique such as proposod by Linnette [IL]. This would Ieave a time sorics of the MID that is duc entirely to convective mixing or other cusus, thus cnabling a meh better quantitative analysis of the convective process. This is suggosted as the next logical extension of the rosearch reported in this paper. 



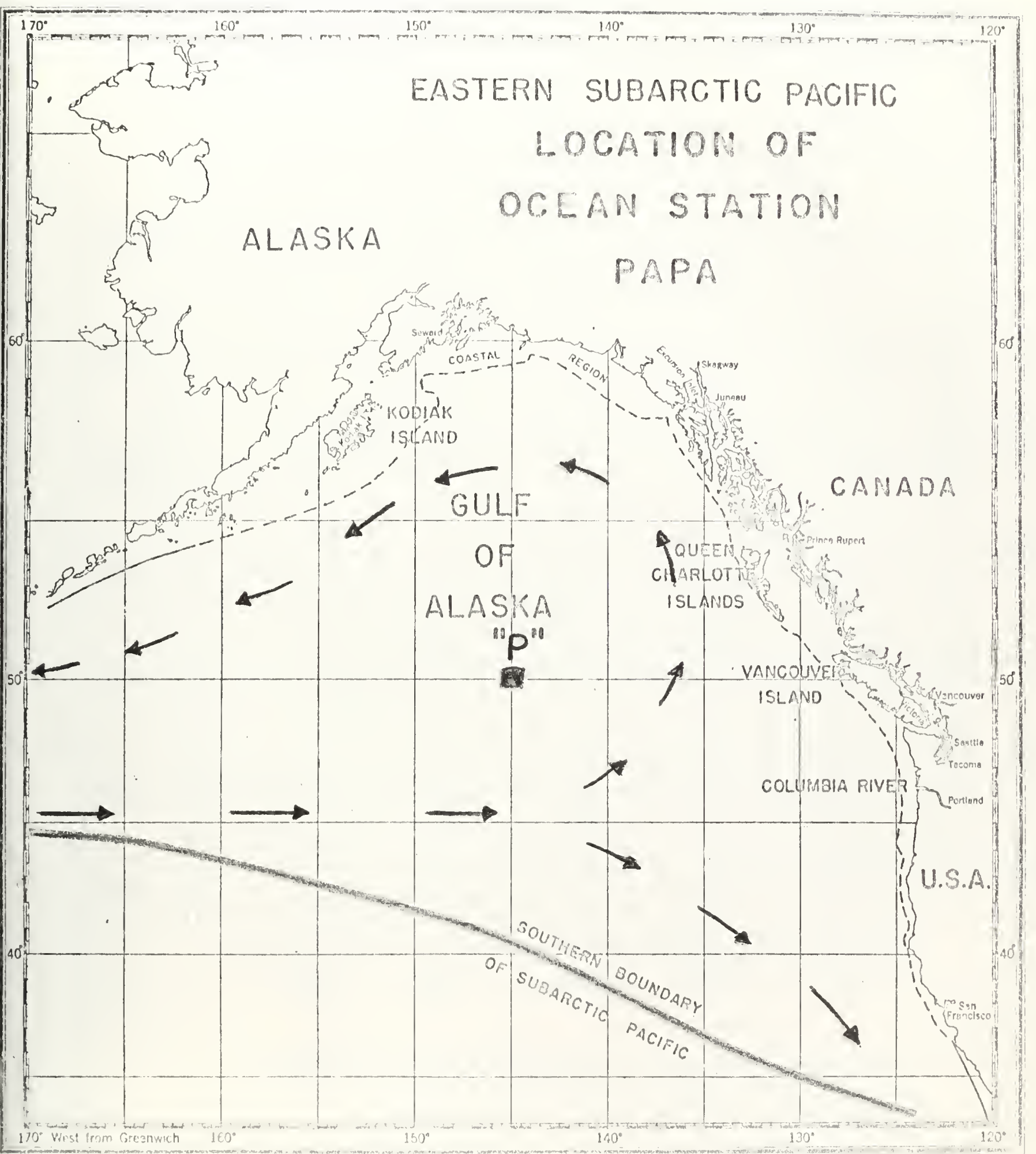

EIGUR: 1 



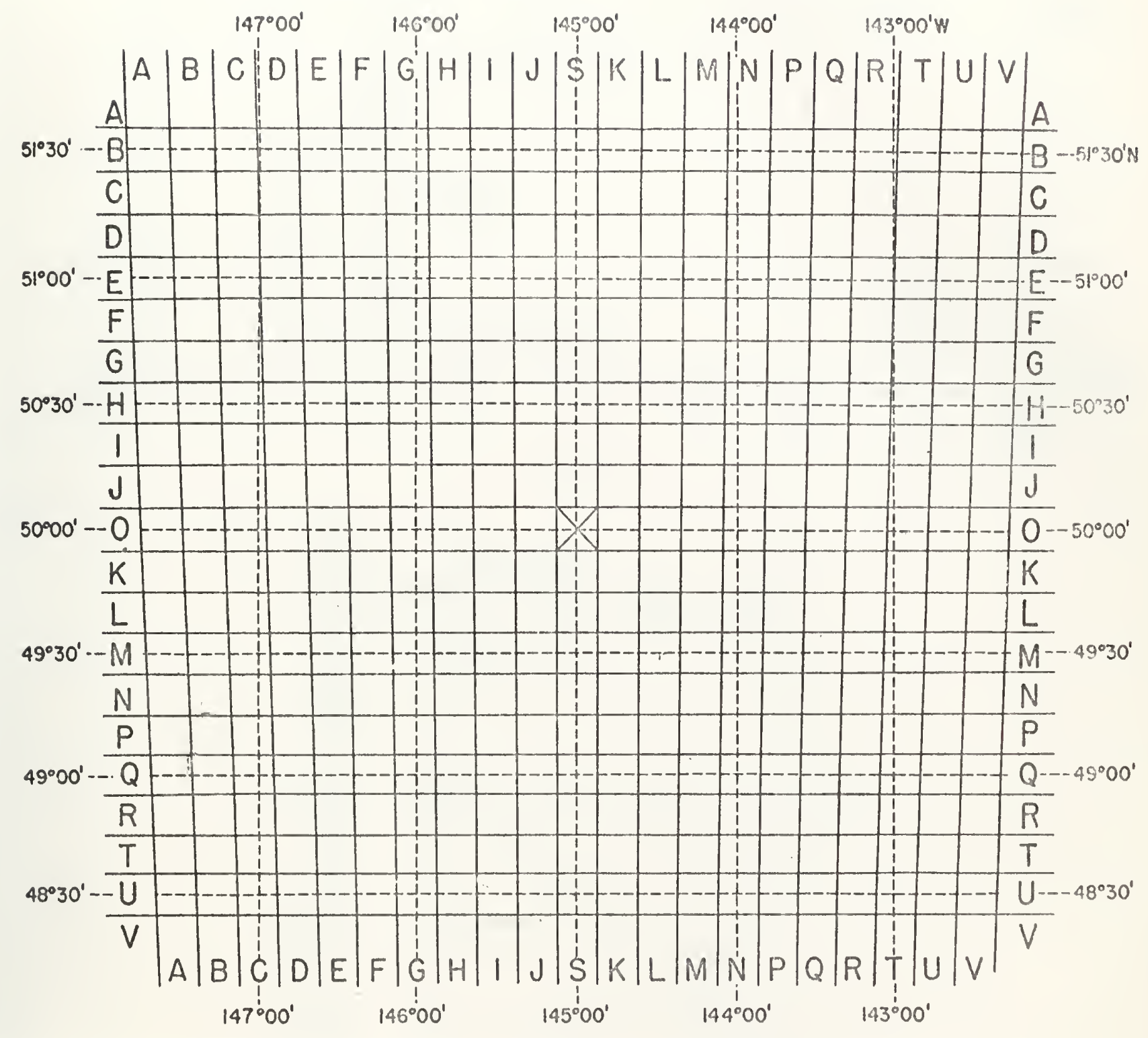

Figure 2. Position-Indicating Grid for Ocean Weathor Station Prpa, itid a iorcator Projcction of a Lat:tude and Longitude Grid Superimposed 

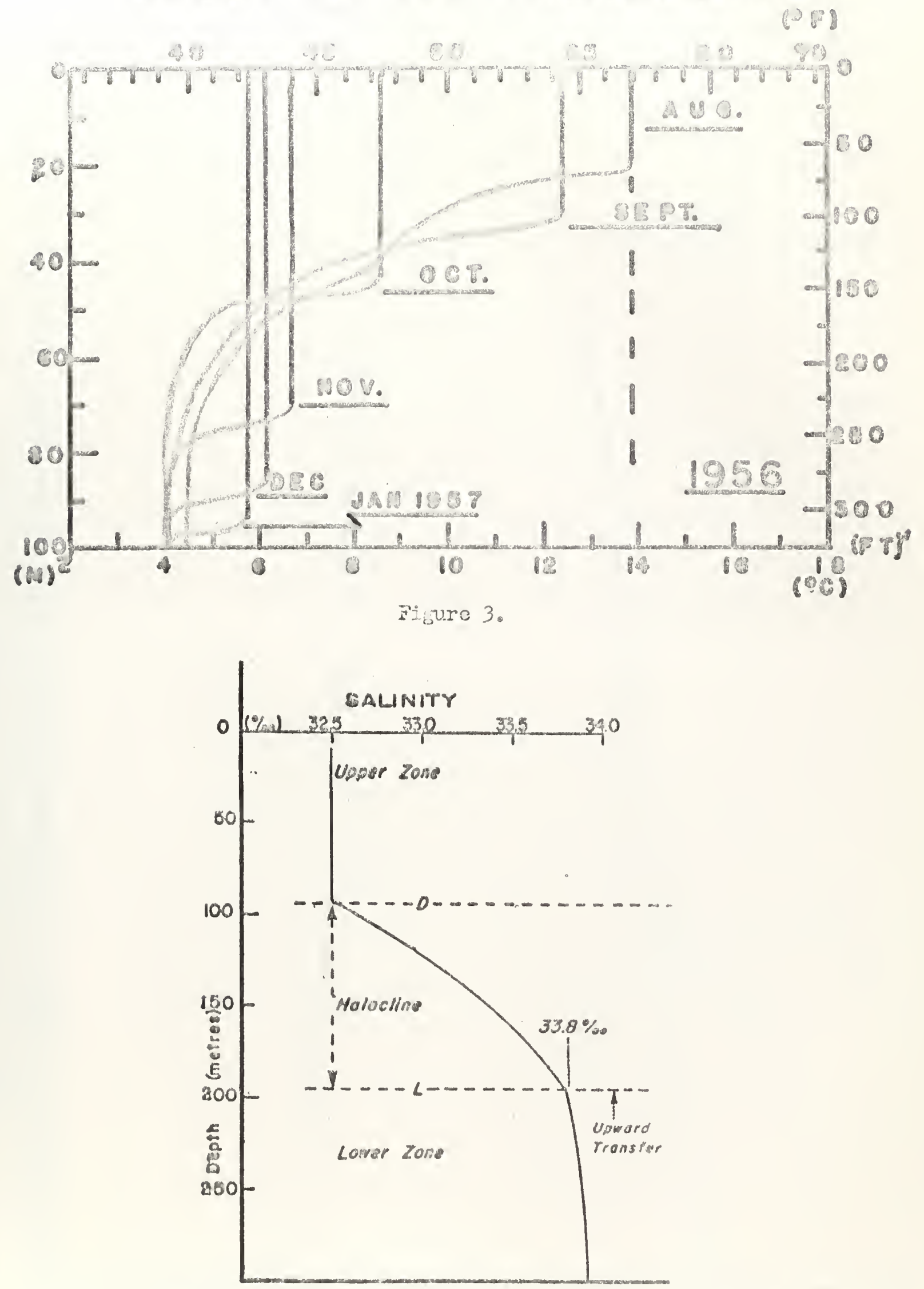

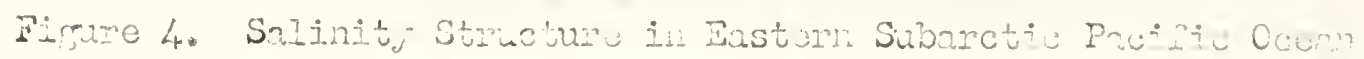





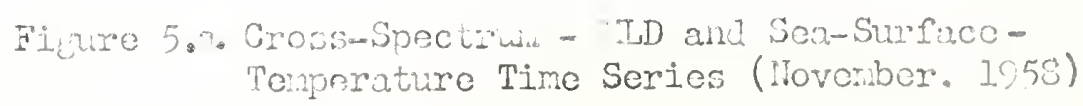

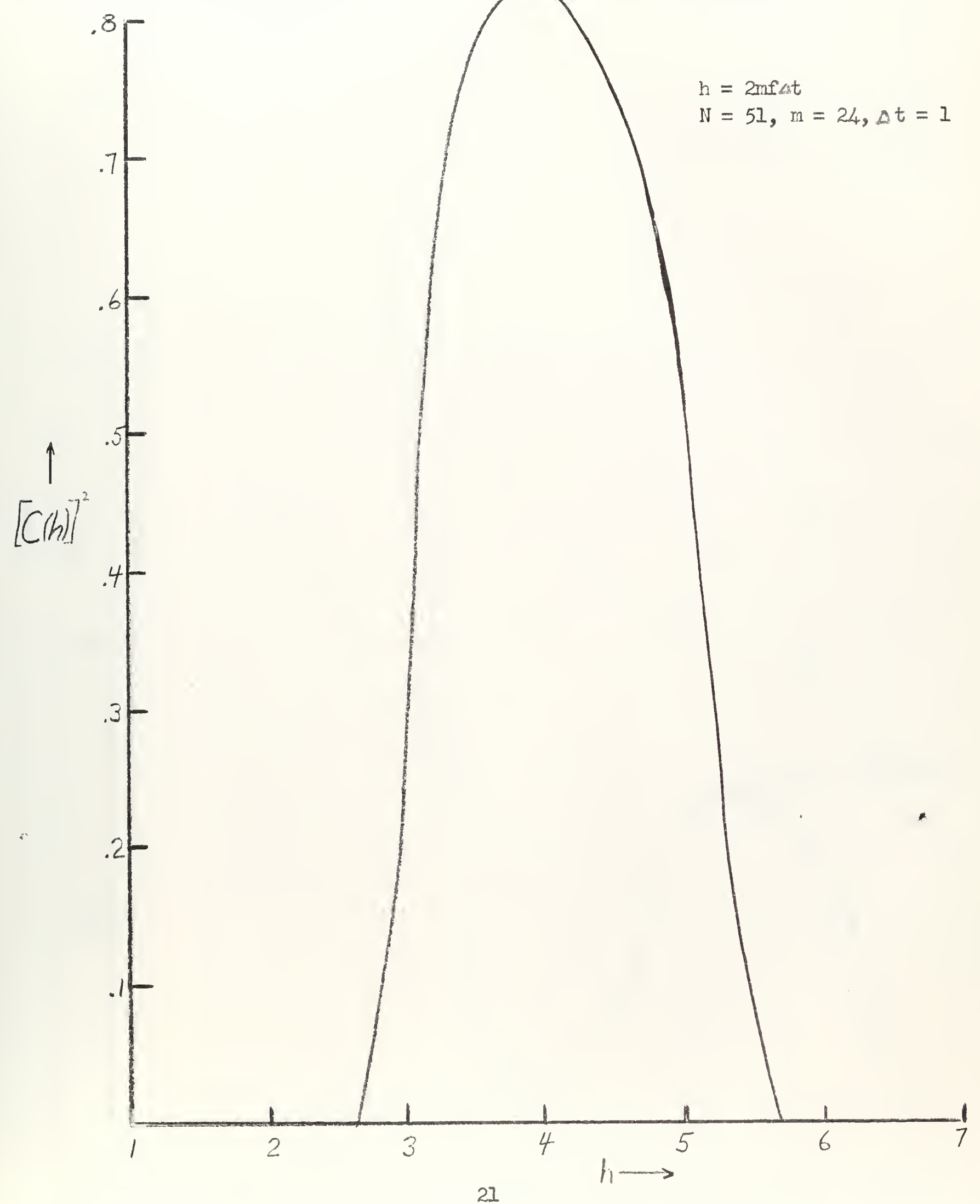





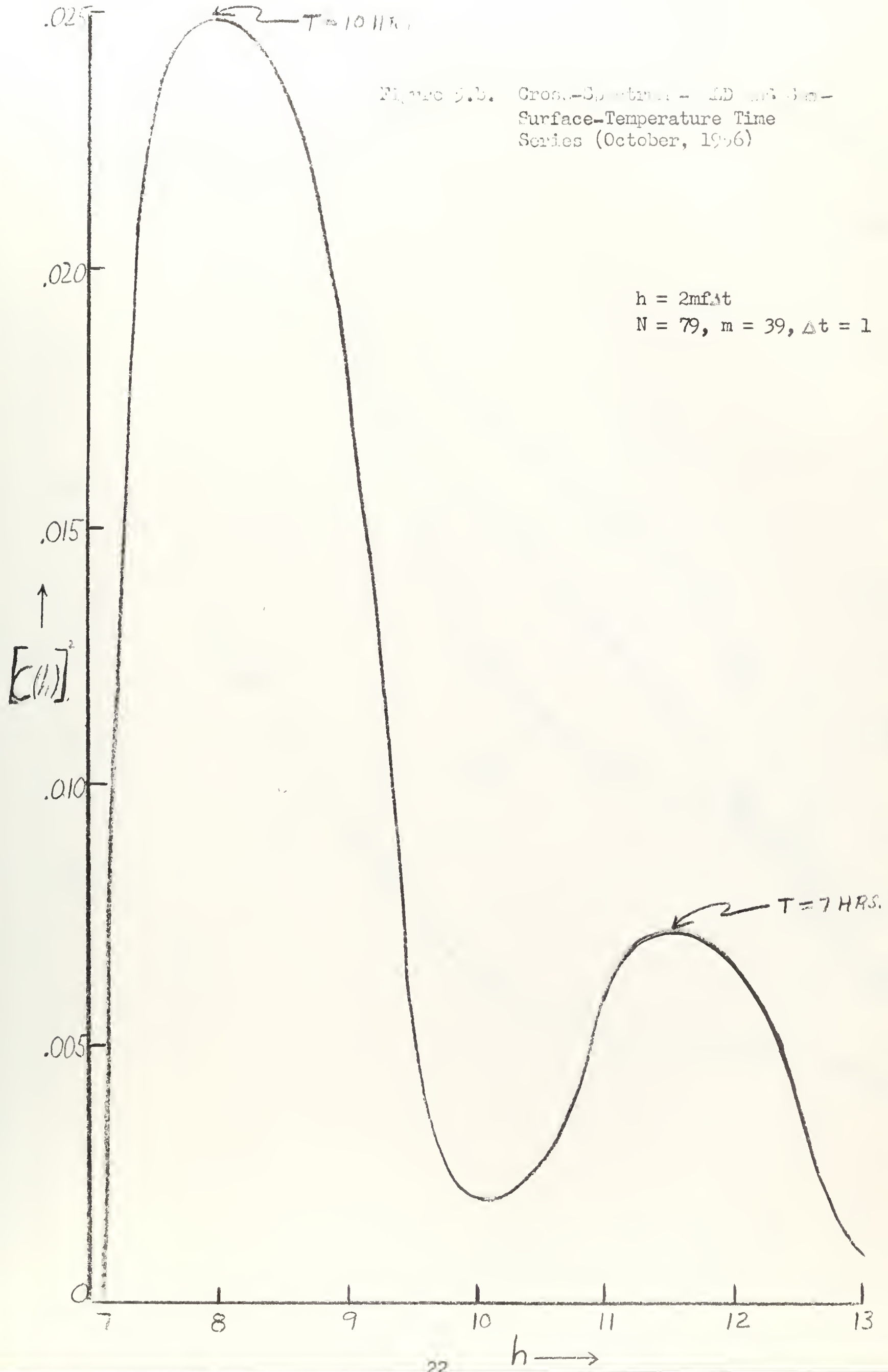





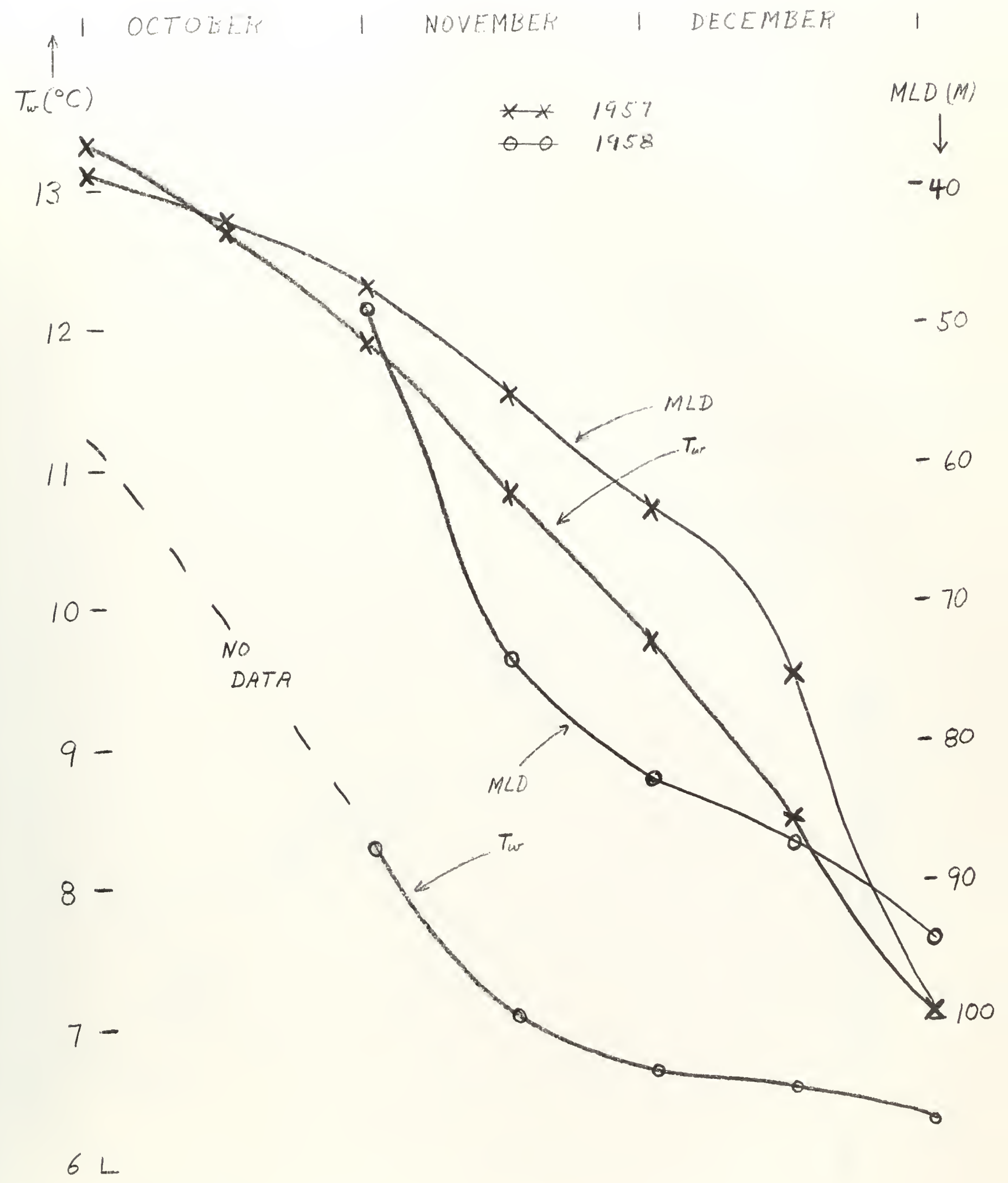





$$
\text { - }
$$




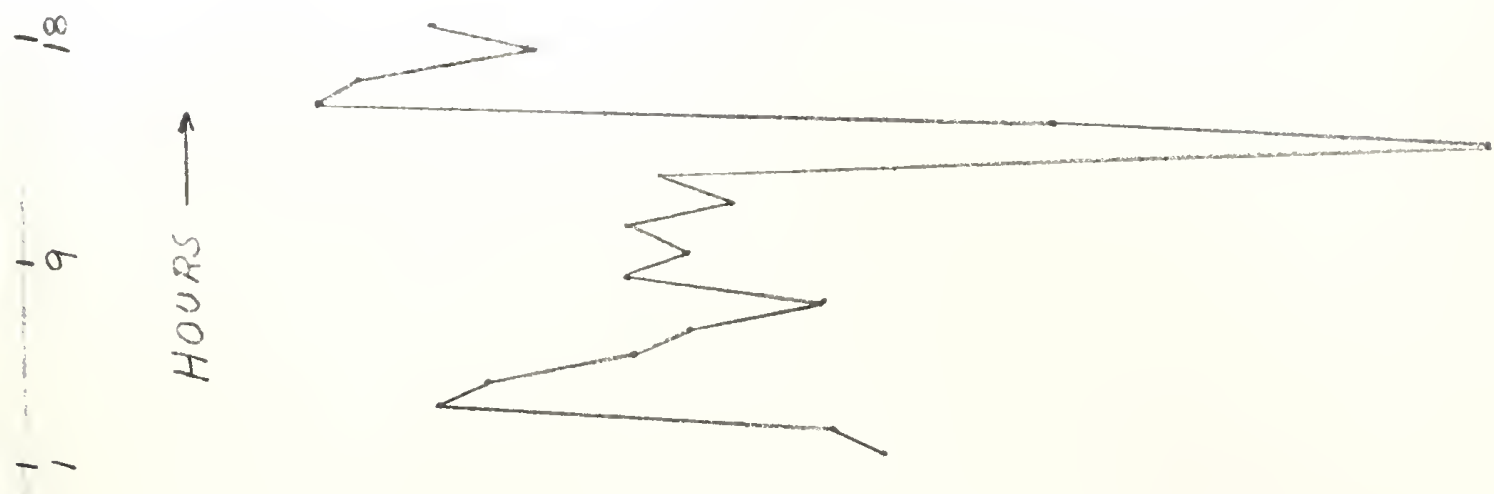

$\frac{1}{m}$

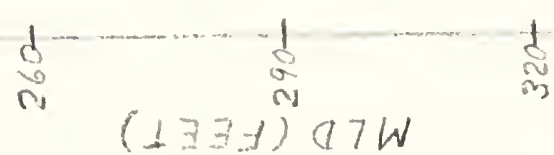

b

$-5$
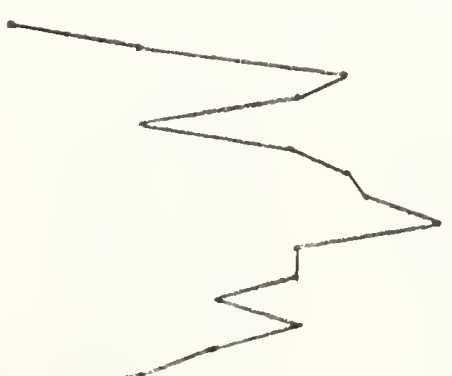

넝

$\uparrow$

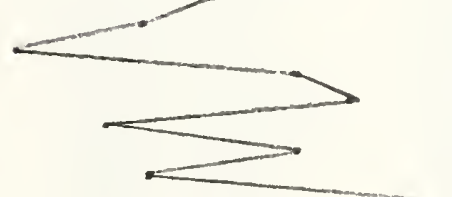

Q

站

क

$\begin{array}{rl} & 5 \\ -n & 0 \\ -n & x\end{array}$

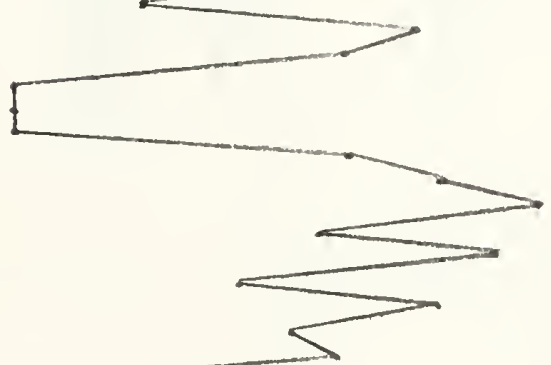

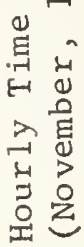

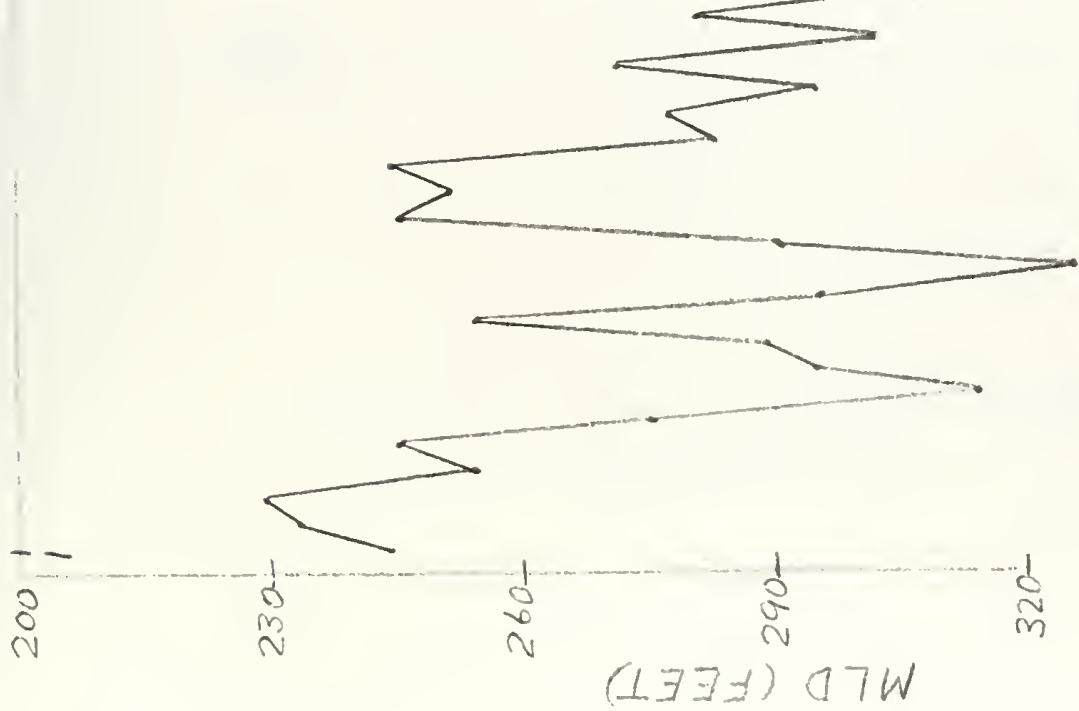

$\underset{\substack{\infty \\ 0 \\ 0 \\ 01 \\ 01}}{\infty}$ 



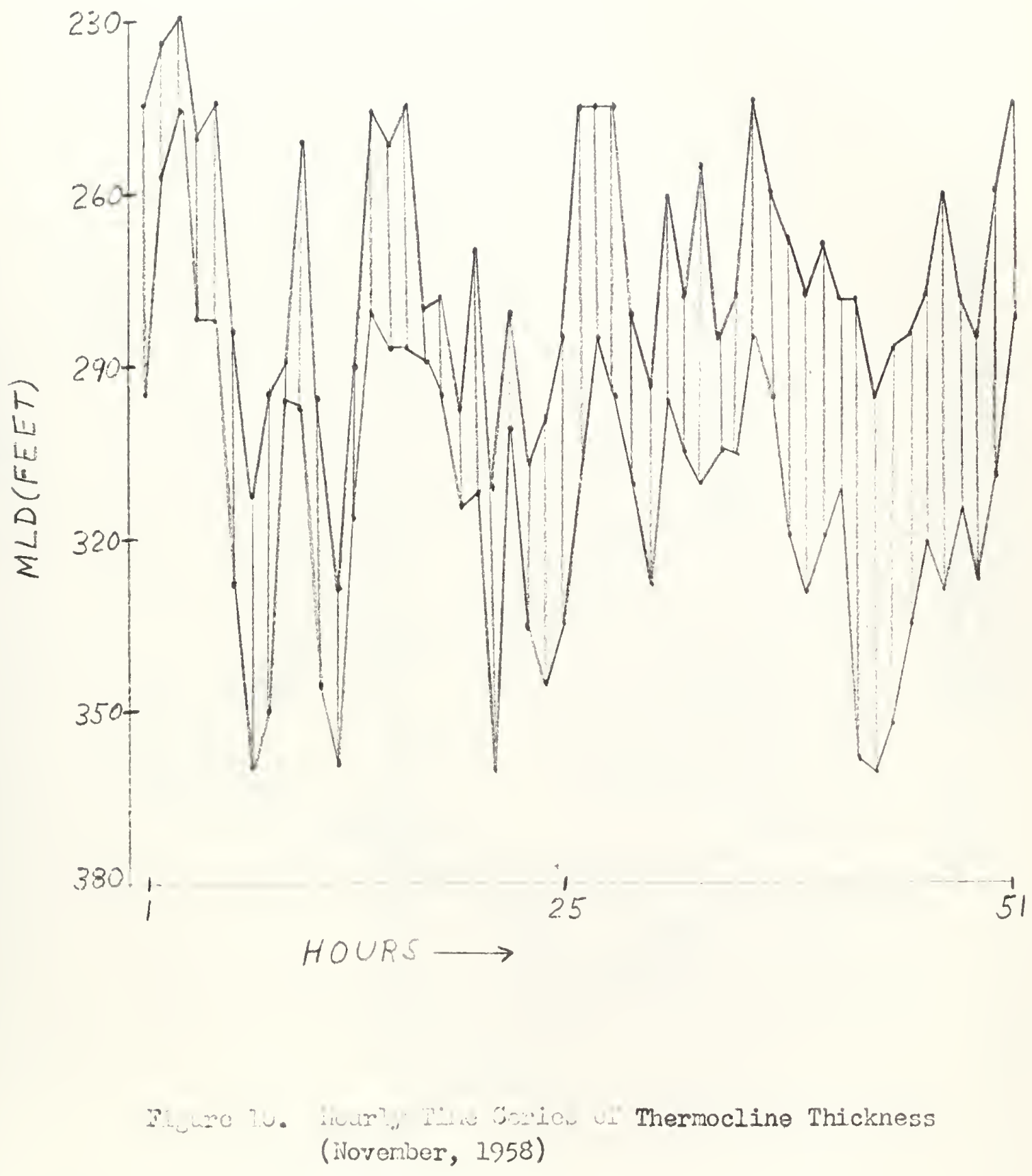





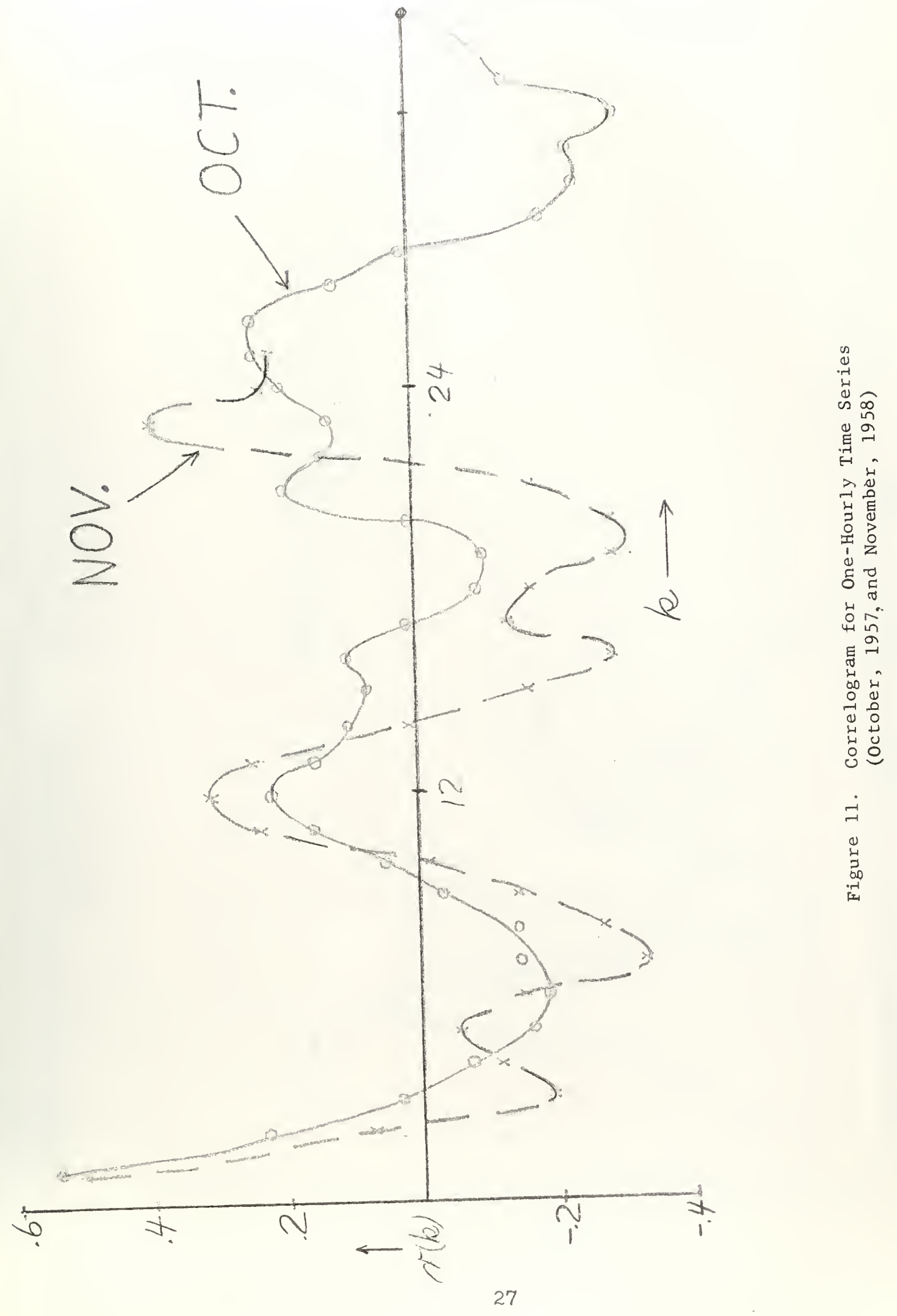


$+$ 


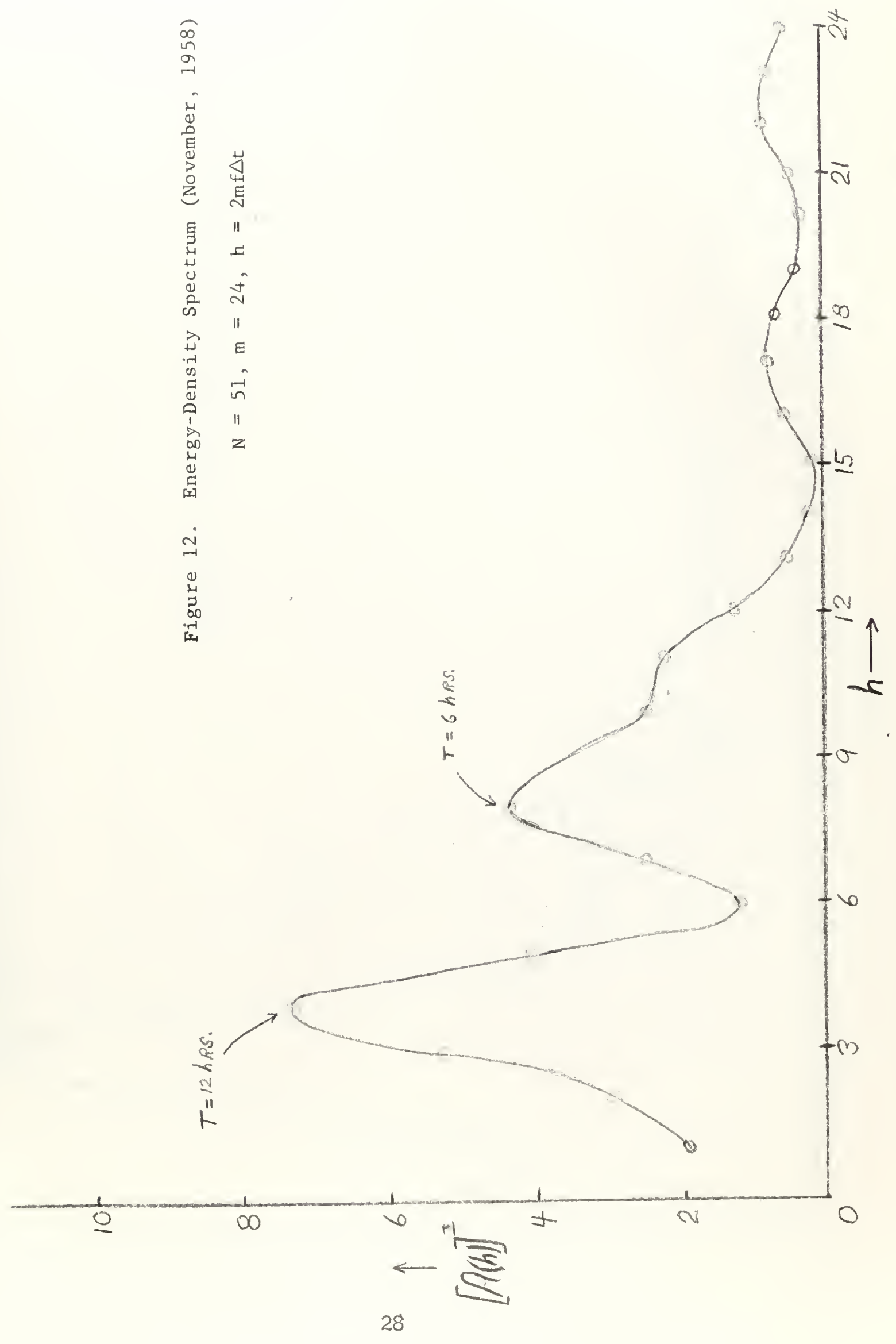





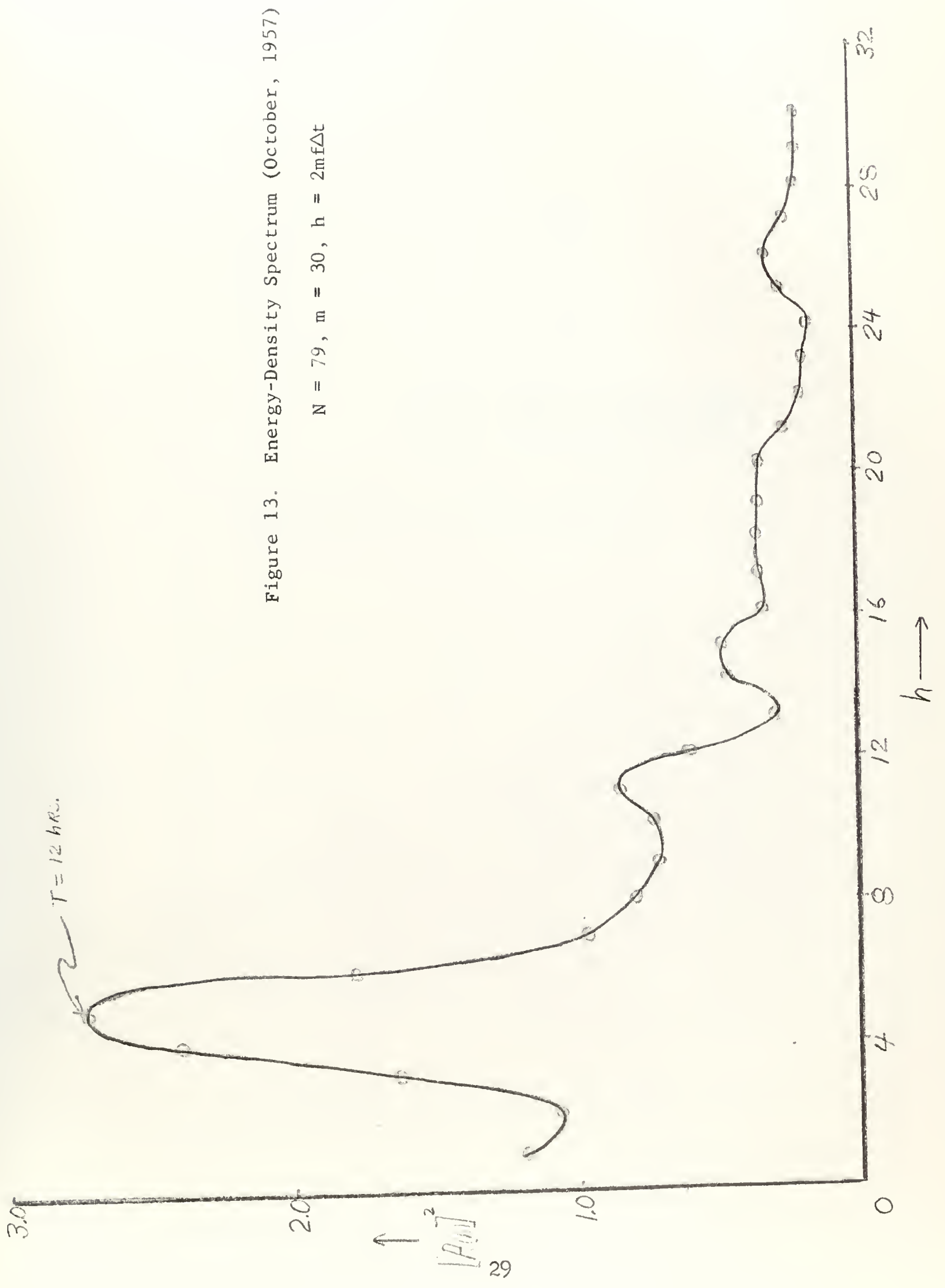



Table I

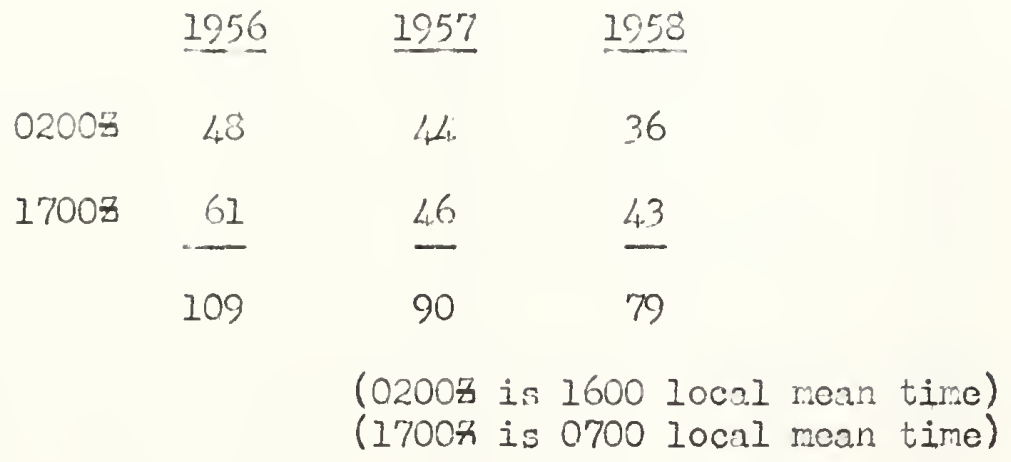

Bathythemograph Soundings Available 

02025

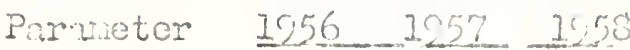

$T_{W}$

$\mathrm{T}_{\mathrm{a}}$

$\mathrm{T}_{\mathrm{a}}-\mathrm{T}_{\mathrm{W}}$

$\mathrm{T}_{\mathrm{dp}}$

$\mathrm{T}_{\text {Wb }}$

RII

$$
\text { (RH:-II }
$$

F

FF

$\mathrm{H}_{1} / 3$

$\left(T_{W}\right)_{-2}$

$\left(T_{a}\right)_{-}$

$\left(T_{c}-T_{W}\right)_{-2}$

$(\mathrm{FF})-5$

$\left(\mathrm{H}_{1} / 3\right)$

$\mathrm{P}$

(P) -5

GPM $_{5}$

$\mathrm{T}_{5}$

$\mathrm{RH}_{5}$

$$
\begin{array}{lll}
-.005 & -.903 & -.649 \\
-.635 & -.583 & -.554
\end{array}
$$

.369

$\begin{array}{lll}.167 & .266 & .272\end{array}$

$\begin{array}{lll}.028 & .266 \quad .333\end{array}$

$.180 \quad .107 \quad .212$

$-.046 \quad .389 \quad .012$

$\begin{array}{lll}-.200 & .686 & -.089\end{array}$

$-.925-.879-.793$

$-.684-.646-.228$

.314

.019

.302

$-.073$
$-.3144 \quad-.146 \quad .104$

$\begin{array}{lll}-.519 & -.284 & -.008\end{array}$

$-.262$

.352

0.172

$-.223$

.525

$-.389$

$.039 \quad .170 \quad-.342$

$.041 \quad .327-.215$ $\begin{array}{llllllllll}.118 & -.1463 & -.043 & .215 & -.419 & .1143 & .169 & -.437 & -.050\end{array}$

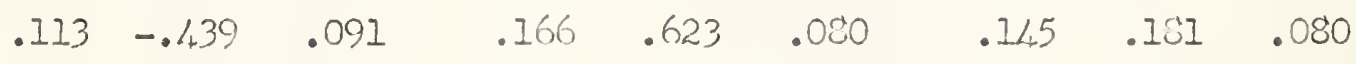

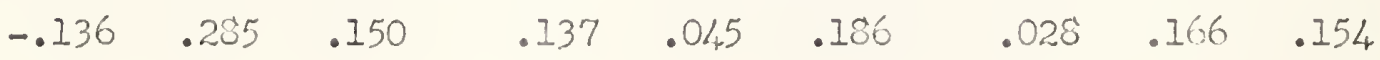

02005 3nd I700z

$1256-125 ?-1258$

$-.871-.829-.734$

$-.502-.189-.333$

.369

$\begin{array}{lll}-.242 & -.050 \quad .062\end{array}$

$.092-.211 \quad .063$

$\begin{array}{lll}.141 & .263 & .238\end{array}$

$.049 \quad .327 \quad .148$

$.276 \quad .004 \quad .231$

$.047 \quad .360 \quad-.062$

$-.127 \quad .581-.060$

$-.899-.726-.819$

$\begin{array}{lll}-.505 & -.502 & -.277\end{array}$

.383

$-.143 \quad .311-.115$

$-.192 \quad .583-.245$

$-.107-.027-.090$

$.047 \quad .125-.150$

Simple Iincar-Gomelation Cocfficients

between the If Primary Parmeters and the IID 


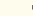




\begin{tabular}{|c|c|}
\hline $\begin{array}{l}\text { Ser-Surface-iemperatire } \\
\text { Lne Di Houms }\end{array}$ & $\begin{array}{c}\text { Cormolation Coefficionts } \\
\text { With the liD }\end{array}$ \\
\hline 0 & -.31075 \\
\hline 2 & -.88409 \\
\hline 5 & -.07828 \\
\hline 8 & -.87576 \\
\hline 11 & -.87173 \\
\hline $1 / 1$ & -.86479 \\
\hline 17 & -.86329 \\
\hline 20 & -.561 .25 \\
\hline 23 & $-.8518 ?$ \\
\hline
\end{tabular}

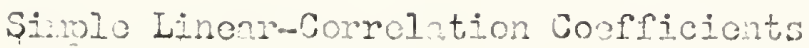

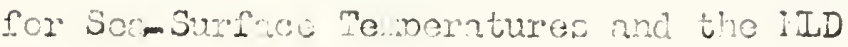



Toble IV

$$
\begin{array}{ll}
\text { Lincor-comelation cooficient } & \\
\text { (for } T_{\mathrm{S}-2)} \text { ) } & -.884 \\
\text { Standard crior of the estimate } & 30.33 \\
\text { Range of residuals } & 121.2
\end{array}
$$

Regression equation: $i L D_{\text {est. }}=1152.94-20.24\left(\mathrm{~T}_{\mathrm{S}-2}\right)$

Regression Results for One Indepondent Variable

(1700z, 1956) 



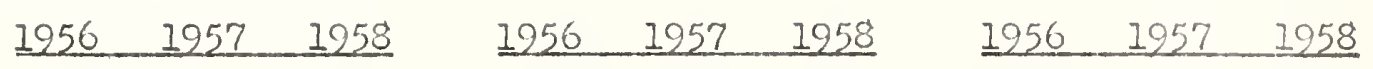

( $\mathrm{T}_{\mathrm{W}}$ and $\mathrm{T}_{\mathrm{W}-2}$ included, $\mathrm{T}_{\mathrm{Q}}-\mathrm{T}_{\mathrm{W}}$ and $\left(\mathrm{T}_{2}-\mathrm{T}_{\mathrm{W}}\right)_{-2}$ onitted)

$\begin{array}{llllllllll}\text { RI }^{\prime} & .950 & .941 & .864 & .915 & .831 & .915 & .909 & .874 & .863 \\ \mathrm{SE} & 26.5 & 14.4 & 26.7 & 31.4 & 18.0 & 19.4 & 29.9 & 15.8 & 21.0 \\ \mathrm{RR} & 80.4 & 45.4 & 29.9 & 104.8 & 49.6 & 59.8 & 118.8 & 57.1 & 102.5 \\ \overline{\mathrm{IID}} & 210.1 & 179.4 & 273.3 & 212.7 & 170.5 & 279.6 & 211.6 & 174.8 & 276.8 \\ \mathrm{~S} & 67.3 & 32.4 & 37.0 & 64.9 & 25.0 & 36.27 & 65.7 & 29.0 & 36.5\end{array}$

$$
\left(T_{a}-T_{W} \text { and }\left(T_{a}-T_{W}\right)_{-2} \text { included, } T_{W} \text { and } T_{W-2}\right. \text { omittad) }
$$

$\begin{array}{llll}R^{8} & .950 & .917 & .910 \\ \text { SE } & 26.5 & 30.9 & 29.8 \\ R R & 80.4 & 104.4 & 121.8 \\ \overline{I I D} & 210.1 & 212.7 & 211.6 \\ S & 67.3 & 64.9 & 65.7\end{array}$

linltiple-Regression Results for 18 Independent Variables 

Table VI

Wultiple-correlation coefficient

(for 18 independent variables)

.896

Linear-corrclation coefficiont

(for $\mathrm{T}_{S}$ and $\mathrm{T}_{\mathrm{S}-2}$ ) -.814

Standard error of the estimate 22.15

Range of residuals $\quad 72.0$

Standard deviation 43.8

Three-Year Averoges for Resression Results 

1. Ball. F. K., Control of Inversion Heicht by Hcatins Puartorly J. R. l'et. Soc.: Vol. 86, No. 370, pn. 483-4\%, 1960.

2. Clarin, Firion $J$., The Influence of Winds and Relative ihuridity on the Sexson?. Themocline + t Decan Station "P", iS Thesis, U. S. Mval Posteraduate school, 1961.

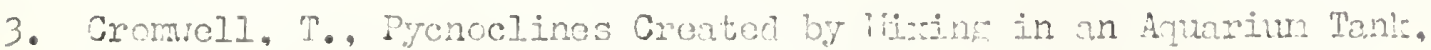
Journal. of liarine Rosearch, Vol. 18. Io, 2., pp. 78-82, 1960.

4. Defant, A, Physical Cceanomraphy, Vol. I., Pergarion Press, 1961.

5. Magen, D. I1.. An Objective Eorscast Technique of the lizred-Laver Depth durin the lionth of lloymber at Ocean Station Papa, U. S. Naval Postgraduate School, unpublished manuscript, 1962.

6. -............. Fisheries Rescarch Board of Canada, Pacific Oceanosraphic Groun, Data Recorn, 1956 Ocmn Weathon Station PAPA "inmennint Report. Joint Committee on Oceanography, Nanaimo, B. C., 1957.

7. …_-_.-., Fisheries Resenech Board of u.nada. Paciric Occanographic Grou, Dat? Record, Ocean Weather Station PAIA linuscrint Report Series. Innaino, B. C., ifo. 14, hy 1958; Ho. 4d, Aoriz 1959.

8. …......., Annual Report of the Pacific Ocennographic Group, Pishories Rescarch Board of Canda, Pacific Occanogranhic Troup. Nainmo, B. C.. 1961.

9. Fleming, R. H. Wotes concornins the Holocline in the lortheastern Pacific Dccan, Journal of Karine Rescarch, Vol. 17, pp. 158-173. 1958.

10. Geary, J. F.. The Hifect of Wind noor the lixed-Layer Depth, lis Thesis. U. S. Waval Postgraduate School, 1961.

11. Giovando, I. F., The "Ocean" System for Assessment of Bathythermogroms, Fisheries Research Board of Canada. Pacific Oceanographic Group, Nanaimo, B. C., 1962.

12. Lacvastu, T., Factors Affectine; the Temperature of the Surface Layer of the Sea, Socictas Scientiamm Fennica, Commentationes Physicolathomaticae XVVI, 1960.

13. LaFond, E. C., Factors Affecting Vertical Temperature Gradients in the Uppor Lavers of the Sea, The Scientific 1:ontily, Vol. LXXVIII, Ho. 4, pp. 243-253, April 1954.

14. Linnette, H. M., Statistical Filters for Snoothin and Filtering Fqually Spaced Data, U. S. ivavy Electronics Laboratory, Report 1049, 1961.

15. Hiler, r., Tuley Spectmu, Cross-Spectra and Powor Spectra, Fortran, CO-OP lianual, IDGGUUCSD TUREY, 1961. 



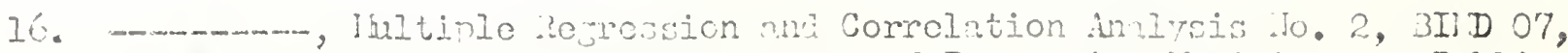
Division of 3iostatistics. Devartment of Preventive liouicine and Public fiealth, School of Verlicine, University of Californic, Anust, 1960.

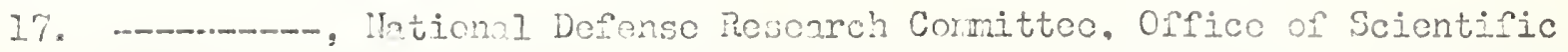
Rescarch ane. Devoloment, The Apritication of Oceanography to Subsurface Varfare, Technical Roport of Division ú, Vol. 6A, 1946.

18. Pattullo, J., Mixed-Layor Depth Detemined Prom Critical Gradient Frequency, Scripis Institution of 0cannography. SIO Referonce 52-25, Roport io. 29, liny, 1952.

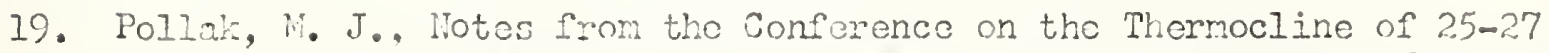
liny, 1952. The chesa, arke 3ay Institute of the Johns Joplins University.

20. Tabnta, S., A Study of the Hain Factors Influcncing the Tomperaturo Structure and its Forecasting during the Iloating Season, Fisheries Resenrch Board of Canada, Pacific Oceanorraphic Group, itanaimo, B. C., 1962.

21. Tabata, S., Terroal Changes of Salinity. Tonporature and Dissolved Oxygen Content of the Water at Station "P" in the Northern Pacific ocean, and Sone of their Determining Factors, Fisheries Resoarch Board of Canada, Pacific Occanofraphic Mroup, Itanairo, B. C., 1961.

22. Tabata, S., The Relation between Wind Speed and Surner Isotherral Surface Layor of Vator at Ocean Station "P" in Fastorn Subarctic Pacific Occan, Fishories Research Board of Canada, Pacific Occanocraphic Group, Nanaino, B. C., 1962.

23. Mully, J. P., M. Pirart and R. K. Lnne, Airborne Radiation Themoneter linrl: I Foasibility Tests, Vianuscript Roport Serics No. Gl, Fishories Resoarch Board of Cnnaca, Pacific Oceanographic Group, Nannino, B. C., 1960.

24. Ufford, C. W., Internal Waves in the Occan, Anerican Geophysical Union Transactions. Vol. 20, lio. 1, Fobruary, 1947.

25. 7ettel, R. A., leteorolorical Factors Affecting Mixed Lnyer Depth Fluctuations, is Thesis, U. S. Naval Postgraduate Śchool, 1961. 



\section{APPIPNDIX}

Hent Transport in the Sea and Axchnee across the Air-Soa Interface A. Thermohaline convection. The vertical displacemont of mall parcels of veter occurs whon a smil part of a vator mass is hearior than the vetor underneath it. To restore this unstable condition to equilibrium, the heavier water tends to sink wile the lighter water rises. Associated with these forced vertjcal novenents of mall parcels thore is also a transm port of the characteristic properties of soa water in a vertical dircction which lcads to an equalization of any vertical differences in these proportics which my be present. It is believed that convective mixins is as important an agent of heat transfer in the occan as wind stirring luring the cooling season $[2,12,20]$.

An initial increase in the density of small particles at the surface accompanies an increase in salinity (due to evaporation, or to the formation of ice) or a decrease in temperature. One or more of these in combination may be involved in thermohaline convection. In lower latitudes, where there are only small variations in the tompcrature, tho heat loss is outweighed by the effect of evaporation; in polar regions, in addition to radiation and cvaporation the increase in salinity duc to formation of ice is also effective. In temperate latitudes the heat loss by radiation is the decisive factor.

Convective sensible heat exchange (conduction) between air and soa surface has been studied by Kuhbrodt [4] for the North AtIantic. Iie has shown the convectional heat flux to be approxinatoly $20 \mathrm{gm} \mathrm{cal} / \mathrm{cm}^{2}$ per day during the period of the year when the air is coolor than the sea surface. This value, even as a rough estimate, is too large to be neglected in the heat budget of tho ocean. If the surface of the sea is warmor than the atrosphere, the air is heated at the interface and the vertjonl stratifi- 

cation of the air becomes unstable; the air becores turbulent with a constant replacoment by cool air at the sea surface and the vertical hoat transport becones large.

Values given by Defant [4] for the heat loss in units of gro $3 \mathrm{al} / \mathrm{cra}^{2}$ per day for $50 \mathrm{~N}$ latituce are 116 units due to effective back radiation, 78 units due to evaporation, and 20 units due to convection of sensible heat (conduction) as a yearly average. Certainly, during the cooling season heat loss due to conduction would be even more significant. These values are derived, assuming that the heat exchange through the occan surface occurs independently for each separate latitude belt. Therefore, no meridional heat exchange (by ocean currents and by horizontal nixing) was considered.

B. Dynamic convection (forced vertical mixing due to wind and wave actiond. This process has been vell studied and considered to be the dominant process of vertical rixing in the heating season. Laevastu [12] has proposed an empirical formula for detemining the IUD by significant wave height alone.

G. Dynamic convection due to forced vertical mixing of occan currents can result in convective mixing, and influences the III. This process vas not considered because of the difficulty of measurenent; however, since the Station is located in the conter of the Alaskan Gyral, ocean-current effects are probably smll.

D. Therma conductivity can take place when a vertical temperature sradiont exists in the ocea. Heat is transferred by molecular heat conauction procosses. Defont [4] concludes that this process is insignificant in oceanogranhic investigations due to the extrenely long period involved in the conduction process. Therefore, this process will not be considered in this study. 

7. Mntraimont to turbulence at tie ychocline. During the coolinis scoson in the open ocean, a well-derineci isothomal wurface layor exists which extends downiard to on interface of rapidy decrensing tomperature. Investigations of the subarctic water indicate an isohaline condition to a depth of 33 ) feet, so the offect of salinity on density can be ifnored [23], and thus we my consider the themocline as a pronocline. Because less dense varmer vator overlies dense cold water, we have a stablo condition mech like a surface inversion in the atnosphere. When surface cooling talos place, thereby creating an unstable condition, free convection can oceur. Cromvell[3] has demonstrated that this free convection in a nocel causes a turbulent exchange across the thernocline which is onoway. The fluid particles which nove upward from the region bolow the thernocline are rapidly deforned and mixed throughout the upper loyers; fluid particles which move downard toward the quiet layer below the IID are buoyed upward intact. Thus, the upper layer increases in thickness, but decreases in temperature, at the expense of the lover layer. This same phenomenon is observed when the turbulence is induced by wave action or internal wave action [I]. 






